\title{
ДО ПРОБЛЕМИ ДОСЛІДЖЕННЯ МОВИ ЯК ІНФОРМАЦІЙНОї СТРУКТУРИ
}

\section{Г.А.Балута}

Багатоваріантність та демократизм філософії XX-XXI ст. відкривають нові дослідницькі перспективи та втілюють окремі можливості для розв'язання класичних філософських проблем, серед яких проблема співвідношення ментального та фізичного-онтологічна бінарність, що виражаеться як «основне питання філософії». Поставимо питання: чи існуе в даному співвідношенні провідний (первинний) елемент, що фіксує і визначає його цілісність (якщо вона існує)?

Відомо, що в історії філософії було обгрунтовано наступні підходи: монізм (матеріалізм-ідеалізм), дуалізм (рівноцінність матеріального та духовного), третій варіант (постановка «основного питання філософії» $\epsilon$ некоректною в світоглядному, чи, наприклад, методологічному сенсі). Здається, що можливі відповіді вичерпано, однак існуе низка дослідницьких точок зору, що виводять проблему «на світло», тобто у іншу площину, засновуючи нову філософську парадигму.

Ідеї Р. Декарта, І. Канта, Л. фон Гумбольдта, Ф. Брентано, З. Фрейда, Е. Гуссерля, Л. Вітгенштейна спрямовують у нове русло дослідження свідомості (мови), що дає підстави для створення якісно нової «інформаційної» парадигми, яка, з нашого погляду, $\epsilon$ пріоритетноюо в порівнянні $з$ поширеними онтологічними концепціями та мовно-філософськими варіантами на даний момент часу, оскільки відповідае завданню аналізу свідомості (психіки), тї елементів, способів та передумов їх поєднання. Як правило, інтерпретація онтологічної проблематики в плані співвідношення буття та свідомості, пов'язана 3 пануванням установки про відповідність образу та його реального об'єкта. Між тим, без мови та інформації не існуе ні образу реальності, ні самої

Актуальні проблеми духовності:

зб. наук. праць / Ред.: Я.В. Шрамко

Вип. 11. - Кривий Ріг, 2010, 266-275

ISSN 2076-7382 
можливості її сприйняття.

У філософській традиції мова розглядається як базисна соціокультурна константа, екзистенційно-антропологічна характеристика; тривимірна система семантики, синтактики та прагматики [13]; мова аналізується як мова індивіда (Г. Пауль); елемент мовної сім'ї (А. Мейе); комбінаторна структура (Ф. де Соссюр); цілісна система (Л. Ельмслев); тип і характер (В. Матезіус); формальний об'єкт, що конфігурує психологічну реальність (Н. Хомський); інтерпретаційна схема, що зберігае значення структур людського досвіду (П. Грайс) [14]. Крім цього, мова розглядається в численних лінгвістичних, психолінгвістичних, психологічних теоріях, що, відповідно, також існують у окремих парадигмах. Важливо відмітити, що дані концепції у значній мірі постулюють мову у відриві від іiї соціобіологічної, феноменологічної, психологічної, інформаційно-семантичної природи. Феномен мови продовжуе перебувати поза визначенням його суті, так і залишаючись надскладним явищем невідомої генези.

Свого часу автора зацікавили наступні філософські відкриття: «образ» мови (комунікації) як своєрідного «інстинкту» духовного порядку, необхідної життєвої потреби; ідея мови як інструменту номінації реальності та самоідентифікації; погляд на мовлення як раціоналізацію психічних мотивів несвідомого, постулювання мови як «форми життя». До яскравих у евристичному сенсі можливостей можна віднести аналіз мови як інформаційної структури, що втілюе собою ідею поєднання філософського та фізичного каркасів реальності.

Серед підходів, запропонованих для вирішення даної проблеми, викликае інтерес її вирішення в руслі філософського аналізу, запропонованого Т. Нагелем [9], Д.І. Дубровським [6]. На противагу теорії тотожності чи функціоналізму або ж дуалістичному протистоянню ментального та фізичного, даний підхід дозволяе знайти особливу форму їх єдності-інформацію, тобто передбачається, що тотожність буття і мислення має інформаційний вимір.

Йдеться про наступне: даний зв'язок виступае як екстенсіональна кореляція і розглядається як третій онтологічний вимір і третє поняття онтологічної структури. «На даний час у нас немає концептуальних засобів, які б дозволили нам зрозуміти, яким чином суб'ективні і фізичні властивості можуть бути суттевими сторонами единої сутності чи процесу»,- констатує Т. Нагель [9, с. 105]. На думку дослідника, між ментальним та фізичним існуе не випадковий, а необхідний зв'язок, визначення і доведення якого і складае головну проблему, бо труднощі, пов'язані з визначенням такого зв'язку, відомі як проблема іде- 
альності: ментальні явища позбавлені фізичних властивостей. Однак Т. Нагель впевнений, що є достатньо підстав визнати та обгрунтувати співіснування ментального та фізичного як деяку фундаментальність, поняття, здатне включити Едність обох онтологічних конфігурацій.

На думку Д.І.Дубровського, розгляд проблеми тісно пов'язаний 3 вивченням закономірностей функціонування самоорганізуючих систем, феномена інформації та її кодування, що є частково автономними від засобів і принципів фізичного дискурсу. Автор пропонуе продуктивну ідею, що полягае в обгрунтуванні принципу інваріантності інформації по відношенню до фізичних властивостей її носія (одна і та сама інформація може бути втілена і передана різним за своїми фізичними характеристиками носіям). Звідси випливає обгрунтування нового типу прнчинності - інформаційної причинності (дія визначається в цьому випадку не фізичними вимірами величиною маси та енергії, а саме даною інформацією в умовах кодової залежності в даній самоорганізуючій системі) [6]. Таким чином, даний підхід дозволяе вийти за межі теоретичного каркасу традиційного фізикалізму.

Д.I. Дубровський пропонуе поглянути на проблему, виходячи з нових методологічних та евристичних надбань сучасних досліджень, організованих як специфічний тип наукового пошуку, що, крім дослідження самоорганізаційних та інформаційних процесів, включає дослідження та розшифрування кодових залежностей, зокрема, генетичного коду та геному людини, інформаційних мозкових процесів, аналіз нейро-динамічних кодів психічних явищ. «У нас давно вже є третє поняття, з якого безпосередньо витікае і ментальне і фізичне, і завдяки якому їх актуальний необхідний зв'язок один з одним $\varepsilon$ прозорим. Цим третім поняттям $є$ інформація»,- констатує Д.І. Дубровський $[6$, с.97]. Дослідник висуває низку важливих положень:

1. Інформація необхідно втілена в своєму носієві.

2. Одна і та ж сама інформація може бути втілена (передана) різним за своїми властивостями носіям (принцип інваріантності інформаціï).

3. Інформація може виступати як фактор змін в самоорганізуючій системі.

Звідси випливае наступне: інформапія існуе у визначеній кодовій формі, яку являє її носій; одна і та ж інформація може кодуватися по- 
різному; результат управління в самоорганізаційній системі визначаеться не фізичними властивостями носія, а в.ласне інформацією.

Розглянемо мову як інформаційну структуру, що проявляе чи опосередковуе зміст свідомості шляхом мислення та комунікації. В такому разі поняття свідомості мислиться як розширене за змістом. До нього додаються категорії мови та інформації як її феноменологічні прояви чи атрибути. Виклад та висновки дослідження Д.І. Дубровського складають теоретичний каркас проблеми у її найбільш загальному вигляді, в той час як підійти до «образу» інформації як психофізичної єдності дозволяе філософський аналіз мови, що аналізує її як «ейдетичний» зразок чи згущення інформації. Новизна даного підходу полягає у визнанні мови у якості «універсальної граматики», що фіксуе форми(коди) свідомості і $є$ соціобіологічною константою, принципом організації комунікативної реальності (суб'єктивності).

Скориставшись аналогією, зазначимо, що аналіз загальних властивостей мови дозволяе констатувати, що мовні характеристики відповідають вище визначеному принципу інваріантності інформації, тим самим, зберігається генетичний зв'язок між інформацією (повідомленням-стимулом) та мовою як принципом її організації або ж кодом, умовою оперування та збереження. Отже, можна говорити про ізоморфізм чи спорідненість мови та інформації.

Взагалі тема інформації $е$ однією з найбільш актуальних у сучасній філософії та науці. «Інформаційна» парадигма стверджуе, що інформація $є$ основою реальності. Інформація визначається як зміст, що формуеться в процесі взаемодії матеріальних явищ. Людина $\boldsymbol{e}$ частиною інформаційної основи і водночас її носієм як істота, наділена «розумінням». Формування мислення неможливо уявити без мови як одного $з$ факторів представлення у свідомості смислової та логічної структури реальності. Мову як форму збереження та передачі інформації пов'язують з феноменом імпринтингу - парадоксальною властивістю фіксувати впливи зовнішнього світу і водночас «витісняти» ї у сферу підсвідомого. Цей вдалий, на наш погляд, термін, що перекладається як «відбиток» чи копія, відображує мовну (смислову) сутність інформації.

В даному контексті згадуються ідеї (ейдоси) Платона, який одним 3 перших висловив думку про існування первообразів-ідей як самостійної реальності, по відношенню до якої матеріальний світ $є$ копією чи тінню «світу ідей». Платон вважав, що ім'я, пов'язане з сутністю речі або ж її ідеєю, вирізняє окремі риси, співзвучні з сутністю. Слово «концентрує» реальність та не $є$ її повною аналогією. Наближаю- 
чись до істини як суті, мова наслідуе речі (ідеї), однак не відтворюе їх повноти [12]. (Платонівський та аристотелівський підхід до проблеми відповідності об'єкта і феномена i, відповідно фіксація цієї відповідності у мові, розкриються надалі в низці філософських ідей, зокрема, філософії Ф. Брентано і з особливою яскравістю у «поворотному» лінгвістико-філософському дискурсі XX ст.)

В руслі філософських та психолінгвістичних спостережень набула достатнього обгрунтування «вроджена» природа мови. Існуе точка зору, що інформація «перенесена» мовою і «записана» в нейронній структурі мозку як неусвідомлений генетичний код-передумова розуміння та осмислених дій, притаманних людині як розумній істоті [11]. Можна припустити, що мова (інформапійний код) зберігається в пам'яті (генофонді?) кожного індивіда як несвідома програма, фрагменти якої по-різному реалізуються у свідомій поведінці та діяльності за різних умов. Мова є носіем інформації, яка в свою чергу скеровуе та реалізує всі процеси, пов'язані з інтелектуальною та практичною діяльністю суб'єкта.

Постановка питання тотожності буття та мислення особливо ясно прозвучала в картезіанстві. Р. Декарт, як і пізніше Ф. Брентано, відмовився від наївної віри в буття як незалежного від мислення. В руслі феноменологічної філософії констатуеться, що, з одного боку, буття є формою відчуження свідомості, а 3 іншого-сферою її можливих значень. Власне реальністюе те, що може бути визначене, тобто проявлене в інтенційному (мовному) горизонті. Горизонт пізнання та висловлювання проступае на тлі горизонту мови, предметного змісту свідомості, що організуе «життевий світ». Тим самим на дійсний образ об'єкта накладається специфічний зміст свідомості, що проявляється як «психіка» - буттева проекція свідомості. Мова як субстрат інформації $е$ необхідною онтологічною передумовою буття та мислення, їі пограничним рівнем. (У найбільш загальному вигляді ця теза сформульована у відомій ідеї П. Вейсгербера та гіпотезі Е. Сепіра-Б. Уорфа.)

Цікаво згадати, що давні греки розглядали людину як співвідношення структурних рівнів: anima (душі) - simulacrum (психіки) - corpuscula (тіла). Значення «simulacrum» (видимість) наштовхуе на думку, що, фіксуючи співвідношення душа - тіло - життя (психіка-інформація), давньогрецька думка намагалася підійти до розуміння інформаційно-психічної природи суб'єкта (життя), його мовного вираження, що сприймається нами як реальне.

I. Кант свого часу обгрунтував специфіку зв'язку між чуттевістю, функціями мислення та формами судження і підвів до висновку, що 
чуттеві дані, на відміну від їх мислення та суджень, не можуть бути ні істинними, ні хибними. При цьому чуттєвість покладена в основу розсудку як об'єкт $\epsilon$ джерелом реальних знань. Однак чуттєвість, її вплив на розсудок стає також і джерелом заблуджень, оскільки суб'єктивні враження деформують об'єктивний зміст за аналогією з відхиленням від «траєкторії» істинного значення під впливом деякої сили [7, с. 198]. Що ж спотворюе визначене сприйняття реальності, деформує їі образ? Припустимо, що мова е однією з форм чуттевості, що деформуе дійсний стан справ. На наш погляд, відповідь на це питання криеться в таємниці тотожності буття та мислення як співпадання інформаційних репрезентацій чуттєвих та ментальних структур.

Відомо, що Ф.Брентано поділяв кантіанську ідею, що даність нашого світу являе собою феноменальні дані, таким чином, видима впорядкованість світу є інтенційним горизонтом свідомості і ми не можемо володіти знанням того, наскільки адекватна фіксація реальності у формах нашої свідомості самій реальності. Повсякденна настанова структурної впорядкованості світу є вторинною по відношенню до структурності свідомості [2]. Проте філософ намагався звільнитися від кантіанської дихотомії простору та часу як форм зовнішнього і внутрішнього споглядання, бо вважав вірогідним, що фізичні об'єкти позбавлені властивості едності, схиляючись до думки про феноменологічну єдність даних фізичної та психічної реальності. I ця геніальна здогадка знайшла відображення і подальше обгрунтування в категорії «життевого світу» Е. Гуссерля, що презентувала ідею смислового характеру реальності. Було обгрунтовано, що акт свідомості фіксуе інтенційносмислову єдність фізичного (статичного) і психічного (темпорального).

Мова виявляється формою даної єдності; вона реалізуе синтетичнономінативну функцію і саме тому є статичною (віртуальною) та динамічною (темпоральною) системою. По-друге, $\boldsymbol{\epsilon}$ формальною та проективною умовою єдності світу, його образу, позаяк зосереджує генетичну едність мовних структур на рівні «логік» семантики, синтактики та прагматики. Невідповідності у вигляді інформаційних втрат, семантичних зсувів деформацій логічного апарату штучного чи природного характеру руйнують інтерсуб'єктивний каркас реальності як невірогідний. Очевидно саме ця феноменальна (духовна?) властивість мови призвела до руйнування позитивістської ідеї штучної універсальної мови і підвела до думки про мову як «автономну» реальність або ж функцію відтворення «мовних світів» або «ігор». Філософські чи наукові аб́стракції, повсякденність мовлення, чи, наприклад, автокуль- 
турний горизонт мають мовний генезис, тобто існують у мові, в її межах. Л. Вітгенштейн визначив мову як форму життя і ця ідея, на наш погляд, є однією з найбільш «загадкових» у сучасній філософії.

Виявляеться, що зміст мови набагато глибший, ніж нам здається: 3 одного боку, мова виконуе інформаційно-інструментальну функцію, а $з$ іншого, співстворюе реальність шляхом називання, актуалізуючи генетичні смисли і значення найближчі до реальності (?), що дало підстави визнати її у якості дому буття (М. Хайдеггер) чи сукупності фактів про світ (Л. Вітгенштейн). Ми ніби перебуваємо у мові-смисловому перетині з реальністю, сукупності «мовних» світів, що проявляють, чи, навпаки, розчиняють «реальність» нашого еgо шляхом установок, відповідних чи невідповідних оцінок та ін. У підсумку можна говорити про мову як феномен, що створює образ світу аб̆о ж його форму, тобто є інформацією у її найбільш загальному (ідеальному) розумінні. Цікаво, чи можна уявити мову як інформаційно-кодову основу реальності або ж смислову голограму, якщо брати до уваги її феноменологічне розуміння?

Наприклад, можна мислити, що мова об'єктивуе каркас реальності, його якісні виміри за аналогією 3 математикою, що оперуе кількісними вимірами. Смисли і значення створюють видимість - інформацію шляхом семантико-логічних сполучень, оперують нею, конфігурують чи, наприклад, видозмінюють. Наявність смислу створюе реальність у вигляді мовного відбитку (імпринтинг) і відкриває можливість розуміння та сприйняття, оскільки, перш за все, сприйняття предмета як певного значення $\boldsymbol{\varepsilon}$ переживання його смислу в певному психологічному модусі. В протилежному разі (без смислу) реальність не $\boldsymbol{\epsilon}$ ні об'єктом, ні поняттям. Так само як математичний апарат конституюе фігуру, абстрактна кількість набувае конкретизації як «число», мова завдяки смислу конструюе якість (значення?), що набувае конкретизації у «слові» та реченні-інформаційній оболонці реальності.

На фоні постулювання ідеї мови як смислової форми реалізації зв'язку буття та мислення викликае інтерес низка мовних властивостей, пов'язаних з інтенційністю - установкою свідомості, що поєднує об'єктивний та суб'єктивний образ об'єкта у свідомості, надаючи йому індивідуального забарвлення. Цей процес вибудовуеться як раціональна та смислова обробка чуттевих вражень. Як наслідок, істина чи омана $є$ площинами або перспективами «інформаційної видимості» об'єкта, що є відносною до дійсності.

Також цікаво згадати унікальний «ефект прозорості знаку»-мовний ефект, зафіксований Гуссерлем, який розглядається як один із 
законів психіки. Ми сприймаємо зміст тексту шляхом відмежування від знаково-графічної оболонки (мовної матерії). Таким чином, «матерія мови» стає прозорою. 3 одного боку, це вказує на антропогенетичну спорідненість людини та мови, а 3 іншого, демонструе пластичність мови, її здатність розсіюватися, розмивати або ж відкривати реальність; «концентруватись» - закривати її засобами логічного, інструментального або психологічного впливу, деформувати шляхом інформаційного нагромадження чи втрат, невідповідних смислів та значень, їх редукції, заміни, наявності підтекстів та семантичних нашарувань. Даний ефект можна визначити як ефект «мовної аберації» за аналогією зі світлом.

Дійсно, мова (семантика) розкриває сутності, як це мислить М. Хайдеггер, проте, водночас і приховує їх. Слова, речення, фрази - симулякри, що імітують «присутнє». Чуттєва данність кодується мовою і $\varepsilon$ інформаційною репрезентацією реальності. Мірою цінності інформації в такому разі може виступати ступінь тї відповідності структурній впорядкованості мови та гіпотетичній реальності. Тотожність буття і мислення фіксуеться як факт чи момент відповідності між інформацією та її витоками (мовою та реальністю). Ми бачимо, що суб'єктивна реальність, рефлексивність конституюється мовою, однак сама мова не фіксується як інформація. Можна уявити, мову як інформаційну структуру в її чистому вигляді, ідеальний ейдетичний горизонт, що відбивається в граматичних системах етнічних мов (Е. Гуссерль).

Людина як складна біосоціальна система використовуе інформацію у якості інструменту у складній та неперервній динаміці зовнішніх та внутрішніх самоорганізаційних процесів. Інформація як результат взаємодії людини та світу є однією 3 передумов, що стимулюють ті чи інші ефекти, які в свою чергу викликають відповідні зміни в характері даної взаємодії та різних типах такої взаємодії за схемою стимул - реакція. Наприклад, взаємовплив оточуючого середовища і живої системи; інтерсуб'єктивна взаємодія, у якій відтворюються, «перетинаються» емоційно-екзистенційні горизонти; тілесно-духовні процеси, перетворені (сублімовані) психічною енергією в когнітивні форми, фіксовані різними видами інформації від повсякденного мовлення до об'єктів культур.

3. Фрейд одним з перших у філософській теорії звернув увагу на мовлення як раціоналізовану форму підсвідомого, площину перетину свідомого та несвідомого. Мова несвідомого проявляється у мовленні та культурі як видозміненому тексті у вигляді часто вживаних окремих слів, помилок, символів, натяків і т. ін., які вказують на внутрішні 
витіснені процеси. Особливу роль тут відіграє також енергійно-інформаційна модель психіки, розроблена філософом. В світлі сучасних досліджень така модель дозволяе підійти до аналізу інформаційно-енергетичної природи психіки, відновлюючи давньогрецьку антропологічну структуру. Поглиблення психоаналітичних досліджень дозволило отримати результати у вигляді ідей про внутріпсихічні комунікації, композиційні особливості і стратифікації несвідомого, голографічний характер елементів несвідомого, змістову та інші властивості [10]. Мовлення, таким чином, опосередковуе зафіксовані на глибинному рівні «комунікативні події», виводячи їх назовні як інформаційні детермінанти соціальної та індивідуальної поведінки.

Розглянемо наступну характеристику, притаманну мові, що також є однією із екстраординарних її властивостей. Свого часу Р. Карнап та Л. Вітгенштейн звернули увагу на те, що структури речень пов'язані між собою внутрішніми зв'язками: речення $\boldsymbol{e}$ результатом операцій свідомості, що утворюють нове речення (значення і смисл) 3 попереднього. Таким чином, модель мови можна подати як суб'єкт-об'єктну едність, що виступае умовою логічного зв'язку (як наявності смислу) у тексті, користуючись уявленням алгоритму як системи послідовних правил, що призводить до вирішення певного класу задач або ж є організованою послідовністю дій, допустимих для деякого виконавця. Беручи до уваги ідеї С.А. Лебедєва, зазначимо, що, на відміну від жорсткого алгоритму, алгоритм мови можна розглянути як універсальний алгоритм, що забезпечуе фіксацію едності багатоманіття буття в межах співвідношення ментального та фізичного у відзнятому вигляді. При цьому співвідношення може бути визначене не як детермінація одного іншим, а як певна гра, що здійснюеться в умовах неповної невизначеності і має відкритий «творчий» зміст $[8$, с. 35$]$.

Отже, інформація охоплюе як раціональний та несвідомий і підсвідомий рівні свідомості, об'єктивний та суб'єктивний її горизонти як умови їх едності і взаємодії. Тотожність буття та мислення фіксуеться як факт або ж момент відповідності між інформацією та їі витоками: мовою та реальністю. Аналіз мови та інформації у фокусі феноменологічних, структурних та психоаналітичних досліджень дозволяе констатувати, що мова $\varepsilon$ третім онтологічним виміром та генетичним інформаційним кодом. Проблема співвідношення ментального та фізичного, подальше дослідження мови та інформації знову повертає до перегляду класичної полеміки Платона та Аристотеля, а також їі гармонізації стосовно онтологічного статусу реальності. 


\section{1 Бібліографія}

[1] Ажажа В.Г., Белимов Г.С. К вопросу об информационной первооснове микро- и макромиров Вселенной // Философские науки. 2001. - N1 - C. 125-131.

[2] Брентано Ф. Избранные работы / Пер. с нем. В. Анашвили. - М.: Дом интеллектуальной книги, 1996.- С. 112-122.

[3] Витәенитейн Л. Лекции о религиозной вере // Вопросы философии. - 1998. - oo 5. - С. 122-134.

[4] Bитгенитейн Л. Логико-философский трактат // Витгенштейн Л. Философские работы. Ч.І / Пер. с нем. М.С. Козловой. - М.: Гнозис, 1994.

[5] Гуссерль Э. Кризис европейских наук и трансцендентальная философия // Логос. - 2002. - № 1 (32). - С. 132-143.

[6] Дубровский Д.И. Проблема духа и тела // Вопросы философии. 2002. - 10. - C.92-108.

[7] Кант И. Критика чистого разума. - Симферополь: Реноме, 1998.

[8] Лебеде6 С.A. Предмет и природа философского знания // Вестник Московского университета. Серия 7, Философия. - 2002. - № 5. C. 21-52.

[9] Нагель Т. Мыслимость невозможного и проблема духа и тела // Вопросы философии. - 2001.- № 8. - С. 101-113.

[10] Овчаренко В.И. Осознание бессознательного // Философские науки. - 2001. - № 1.- С. 91-95.

[11] Оконская Н.Б. Импринтинг как системный механизм эволюции общества // Философские науки. - 2001. - № 1. - С. 114-125.

[12] Платон. Диалоги. - М.: Мысль, 1986.

[13] Степанов Ю.С. В трехмерном пространстве языка. - М.: Наука, 1985.

[14] Філософія. Світ людини. Курс лекцій. - К.: Либідь, 2004.

[15] Фрейд 3. Основной инстинкт. - М.: Олимп, 1997.

Надійила до редакциї 19 травня 2010 р. 